\title{
How Students Construct Integer Concept: A Discussion from the Perspective of Ethnomathematics Curriculum
}

\author{
Nur Robiah Nofikusumawati Peni \\ Graduate School for International Development and Cooperation Hiroshima University \\ 1-5-1 Kagamiyama, Higashi-Hiroshima City, Hiroshima, 739-8529, Japan \\ Tel: +81-90-6409-9117Ｅ-mail: nofipeni@gmail.com
}

Received: October 21, 2019 Accepted: November 24, 2019 Published: November 27, 2019

doi:10.5296/ijld.v9i4.15937ＵRL: https://doi.org/10.5296/ijld.v9i4.15937

\begin{abstract}
One of the barriers in understanding the concept of integers for elementary school students is how to create meaningful learning to them. However, the setting up of the situation also needed to help them feeling and experience in it. Ethnomathematics curriculum considers the condition in mathematization to help the students construct the concept of mathematics by themselves. The process of the construction will be discussing in this paper from how the students understand the concept using their own situation. The students quickly to express their idea based on their experience as well as a result shows the step of seeing how their opinion constructed to understand integer concept.
\end{abstract}

Keywords: Ethnomathematics, Integer, Realistic Mathematics Education 


\section{Introduction}

Integers start introduced in grade six elementary schools in Indonesia. This topic consists of operating system for addition, subtraction, multiplication as well as division of positive and negative integer. The number line is the start point of being aware of the existence of a negative number, which has been introducing from grade three to the students. Based on the mathematics syllabi revision curriculum 2018 (MOEC, 2018), the competency indicators for grade six require students to be able to explain negative number in the number line and daily life context, explain and do operate on the negative number as well as solve the problem related with number operation on the everyday life. In fact, during the teaching-learning process, students are emphasizing only to operate the negative number rather than to understand the concept of negative numbers itself. A recent issue in integer, especially in the elementary school students' difficulty in the integer already being raised by many researchers who try to find out how to develop the students' comprehension towards integer. Utami et al. (2018) state that the reason why Indonesian students face difficulties in understanding the concept of integer it is because the requirement to develop meaningful learning, reasoning as well as the conceptual perspective. The students face the barriers to understand the idea of the integer, especially negative integer (Bishop et al., 2014) because of the focus on the teaching integer only on the operation.

Several researchers purpose the approach on how to make meaningful learning: such as associate the concept of the integer with real context (Utami et al., 2018) and using concrete material (De Los Santos, 2013). To set up a meaningful situation to make the problem more contextual for the students, the teacher needs some resources as support. The resources which rarely realized is by using culture itself, whether it comes from the community or the students as a part of their daily life. Emphasizing in the culture as well mention in the curriculum by considering Indonesia is a big country which consists of many islands, races, religions as well as the culture. However, the usage of this natural heritage or culture in mathematics education is still less interest and even superficially. Recently, ethnomathematics is one of the promising approaches which is considered by many researchers to promote culture into mathematics education. The promotion of students' center approaches as well as bring culture to the curriculum context, enhance the students to explore their idea and get the concept of mathematics as well as appreciate others culture as a multicultural country. To reduce the superficial issue due to the difficulty in implement the ethnomathematics approach, the researcher tries to integrate realistic mathematics education to overcome this limitation. The purpose of this study is to investigate how do the students construct their idea on integer concept based on ethnomathematics curriculum. The following research question is being proposed to achieve the research objective: what kind of students' ideas appears and how do they construct those ideas in each activity based on classroom design from the perspective of ethnomathematics curriculum to understand the concept of the integer.

\section{How Integer Being Taught?}

Students use to belief that mathematics that they learn in the school have no relation to what they experience out of the school. It was an old story, but as a researcher, we cannot deny that 
kind of situation still spread everywhere. Students' difficulties in making sense of what they learn inside and outside the school strongly influence their belief toward mathematics. NCTM (1997), Sembiring et al. (2008), TESS-India (2012), Seeley (2016) mention the reason why students have difficulties in making sense of mathematics because they face difficulty to make a connection in and outside of school. Mathematics in the schools used to be deal with formula only that make them weak on the contextual problem as well as construct, comprehend and solve the problem. An integer is one of the topics that senseless for the students, especially for negative integers. Students were taught negative numbers by introducing some phenomena which are used to appear in the textbook, such as weather forecast, multi-storey car park, and bank balance (Bellamy, A. 2015). However, those phenomena are criticized by many researchers, for example, the usage of temperature scale is real and familiar for the students, but this model only introduces adding and subtracting. The teacher would face a similar situation if they were only using the number line as a model. When we consider what kind of mathematical skills should be gain for the students, most of the teachers unconsciously emphasize numeracy, which is written in the textbook.

Stephan and Akyuz (2012) investigating from the previous studies mention about context that being arising by consideration of using model and events are positively and negatively charged particles (Battista, 1983), the activities of patrons in a disco (Linchevski and Williams, 1999), passenger on a bus (Streefland, 1996), lengths of positive and negative trains (Schwarz et al., 1993/1994), LOGO turtles moving along a horizontal number line (Thompson and Dreyfus, 1988) and a two-colored chips scenario (Lytle, 1994; Smith, 1995). Still, those contexts as well not overcome yet the difficulty for the question "why the opposite of e negative makes a positive." As a result, the students only suggested by the teacher to memorize the rule of the integer formula in all mathematics number operations.

Linchevski and Williams (1999) were trying to use the design approach of Realistic Mathematics Education (RME) to create the disco scenario as an authentic context for students. Still, the other challenge is arising on how to help the students transfer their knowledge from one domain to another (ex: from addition and subtraction to the multiplication and division of integer). Another way that being proposed by Bellamy (2015) is teaching events. She found this model as simple in terms of a negative number is a concern. Doing something once is represented by 1 . Undoing something once is represented by -1 etc. Her idea based on (and represents) the convenient idea that to undo something, an equal and opposite act has to be done. This model makes the multiplication of negative numbers possible to explain; however, it also relies on an abstract concept of doing "something" and an ability to identify "an equal and opposite act." However, the limitation of this way of teaching of a negative number is very complicated. Even CCSI (2012) mentions that positive and negative numbers should be introduced in the sixth grade. Still, if we consider how complicated it is, we should think of another option to overcome the issue.

\section{How Students Construct Integer Concept in the Perspective of Ethnomathematics Curriculum}

Peni and Baba (2019) investigate the strength and weaknesses of possibilities approach, such 
as problem posing-problem solving approach, open-ended approach, and realistic mathematics education as a part of the development of ethnomathematics curriculum in the classroom. The result shows that the principle of realistic mathematics education approach, which emphasizes students' creation is more appropriate and in line with the focus on the ethnomathematics curriculum, which shares the same opinion relate to mathematics as a human activity.

The strength from the realistic mathematics education approach also shown in Peni's work on (2019) investigating the strength and weaknesses of ethnomathematics and realistic mathematics education. It is shown that the strength of realistic mathematics education able to cover up the weakness of the ethnomathematics and vice versa. The forming of the ethnomathematics curriculum from this consideration is clearly described within the revised framework, as shown in the following figure.

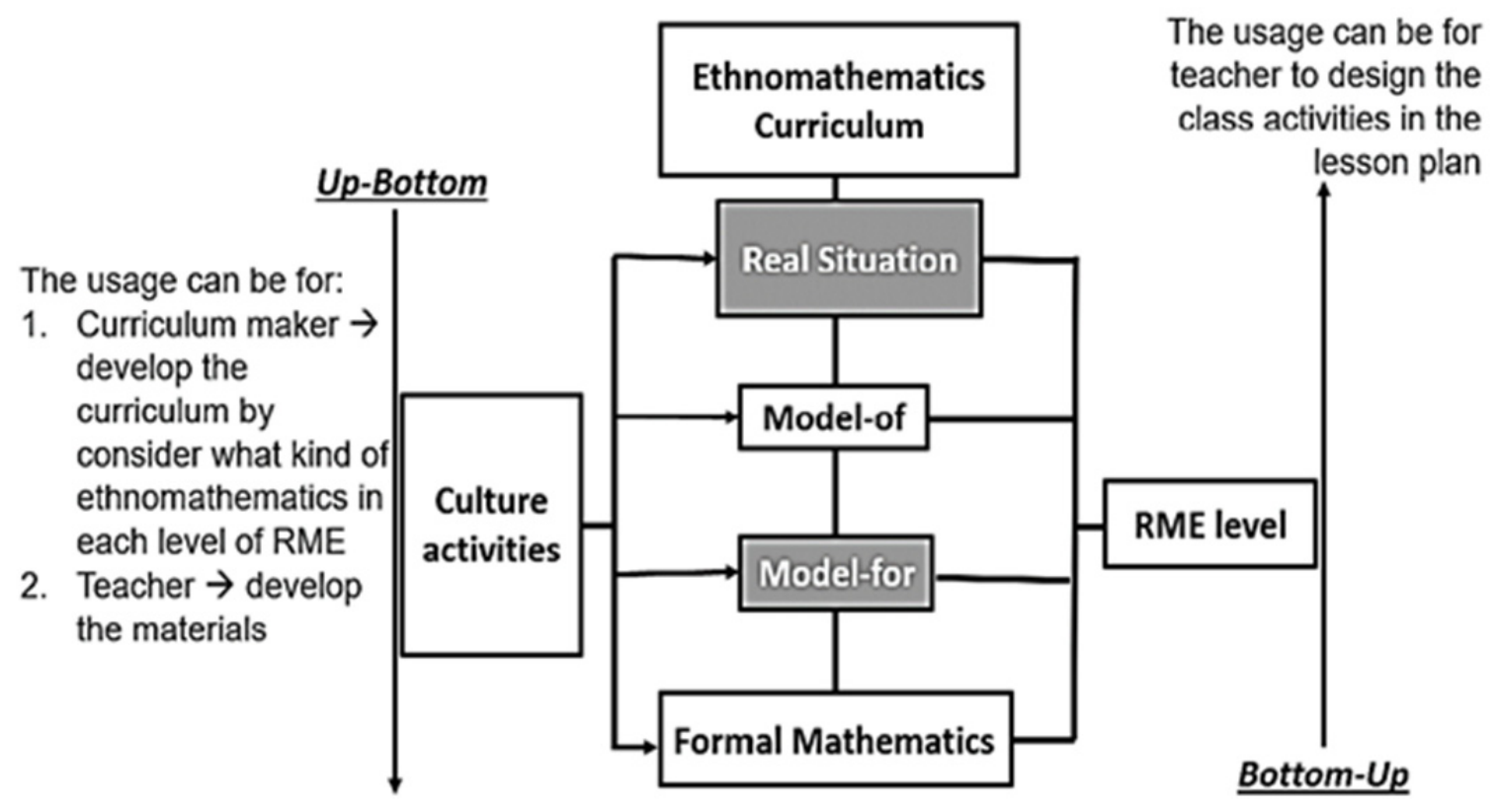

Figure 1. Framework of Ethnomathematics Curriculum

Based on this framework, the researcher develops the classroom design in Figure 2 to analyze students perform in each activity to see how they construct their idea on integer concept.

\subsection{Methodology}

The data have been collected from 60 students from 6th-grade elementary school in Alor Regency, Indonesia. Several data are picked intentionally to be analyzed qualitatively from students' worksheets and video observation to explain how the students construct their idea on the integer concept.

Three phases are cycling in this research (Gravemeijer and Cobb, 2006) before collecting the data in order to validate the framework. 


\section{Macrothink}

3.1.1 Preparing for the Experiment

a. Conducting review on local culture literature.

b. Discussing mathematics education field with teachers and researchers.

c. Designing teaching-learning instrument in setting of Alor local culture, including HLT.

d. Conducting expert and teacher review on preliminary design.

\subsubsection{Design Experiment}

a. Collecting data at the field.

b. Conducting an experiment at elementary schools in Alor.

c. Observation, test and interview the students.

\subsubsection{Retrospective Analysis}

a. Quantitative and qualitative.

b. Analyse the effectiveness of this design.

c. Synthesis for possible remedial of next cycle design.

The researcher and teachers were trying to design the class (Peni, 2019) using a rubber band game as a local culture source for teaching the operation rule of addition and subtraction on integer. The figure below describes how the learning activity is being organized by using a hypothetical learning trajectory in realistic mathematics education.

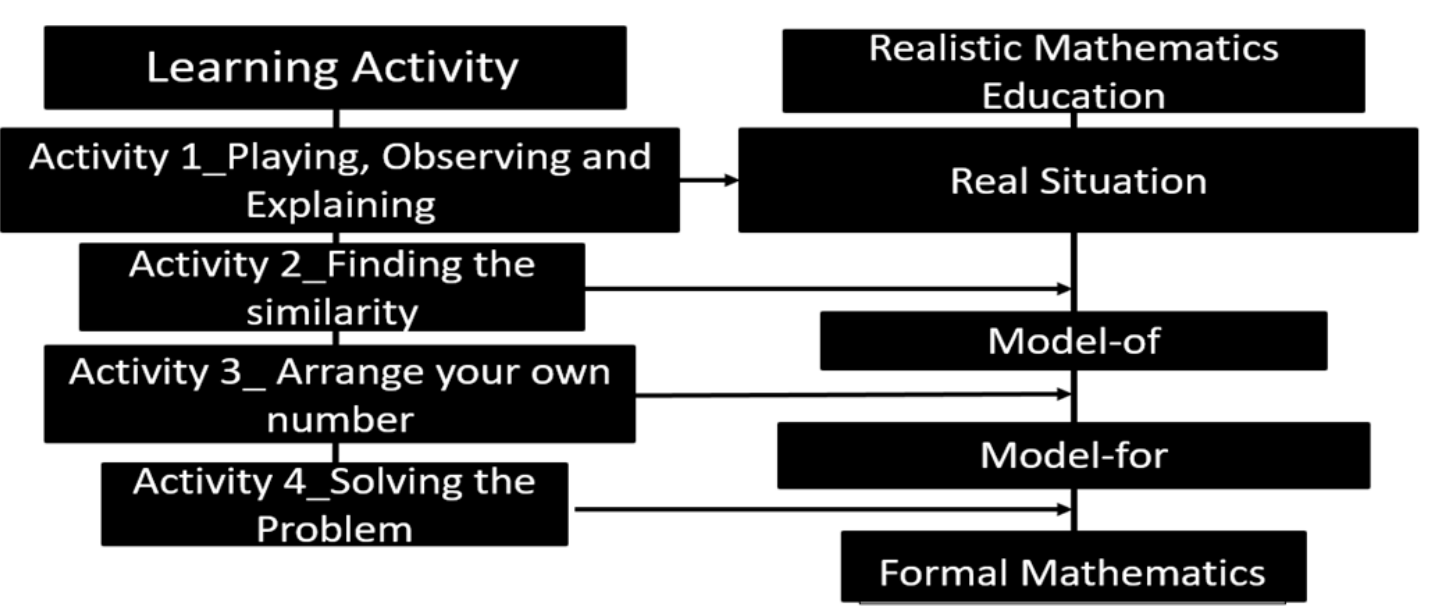

Figure 2. Classroom Design 


\section{MInstitute Macrothink $^{m}$}

International Journal of Learning and Development

ISSN 2164-4063 2019, Vol. 9, No. 4

By using this classroom design, researcher will discuss what happen in each activity and how do the students gradually construct their understanding on integer concept in each level.

\subsection{Discussion}

\subsubsection{Activity 1}

During this activity, the students are divided into four groups, while the other two groups are playing the rest two groups need to observe and write in their worksheet. As the first level of realistic mathematics education, the students are engaged in a real-life situation. Later on, they will use this experience to solve the imaginary problem to see whether they understand the meaning of some of the mathematics expressions, which consists of a positive and negative number. The negative numbers in this activity (see Figure 3) start to exist where the students consider putting a sign "-"to represent the borrow situations during the game.

\begin{tabular}{|c|c|c|c|c|c|}
\hline Kelompok & Nama Pemain & $\begin{array}{c}\text { Banyaknya Karet } \\
\text { Awal }\end{array}$ & $\begin{array}{c}\text { Operasi } \\
\text { Perhitungan }\end{array}$ & $\begin{array}{c}\text { Banyaknya Karet dari } \\
\text { permainan (Untung/Rugi) }\end{array}$ & Jumlah Karet Akhir \\
\hline 4 & Ikram P.Ambara & 4 & - & 2 & 2 \\
\hline & Erik Mau & 3 & + & 2 & 5 \\
\hline & & 5 & + & 1 & 6 \\
\hline & 6 & - & 1 & 5 \\
\hline & Hidayati & 2 & - & 1 & 1 \\
\hline & Fura Muotwa & -1 & - & 1 & 0 \\
\hline & Fajrurahman & -1 & - & 0 & -1 \\
\hline & & -1 & + & 2 & 1 \\
\hline & & 2 & + & 1 & 3 \\
\hline
\end{tabular}

Figure 3. Students' Worksheet

Summary of the result of this activity is the ethnomathematics curriculum that could be labeled at this level is mathematics in a meaningful context (Bishop, 1988; Zaslavsky, 1991; Adam, 2004). It has meant that the researcher defines ethnomathematics as a context in this level. This cultural game draws on the students' own experiences that are common in their environment, which is one of the reasons why the rubber game is being chosen. It is the first stage of how students were starting to construct their understanding of integer.

\subsubsection{Activity 2}

In this activity, the students are required to gather all the data that they observe during the game by sharing their results with the whole class and find the similarity (see Figure 4). In this activity, the teacher guides students to arrange their data by ordering and grouping all the data in the same operation (e.g., all addition or all subtraction). This activity is the bridge from real situation level to a model-of level where the students are required to make their mathematics expression based on the situation in the game. In this stage, students can construct their logic to see (from ordering) the magnitude of the integer (e.g., -2 is smaller or 


\section{Ml Macrothink}

International Journal of Learning and Development

ISSN 2164-4063 2019, Vol. 9, No. 4

bigger than -1). An ethnomathematical curriculum in this stage is the development of mathematical thinking that a child goes through in his/her mathematics Education.

Based on Begg (2001) and Alangui (2017), a justification for this curriculum is that mathematics should start with where the students are then making connections with mathematics in their culture, and then link it to world mathematics. A curriculum of this kind may benefit student learning in terms of students being aware of the mathematics found in their own culture and seeing mathematics as a living and growing discipline (Barton, 1996; Zaslavsky, 1991).

Summary of the result based on activity 2 is ethnomathematics as a tool for mathematization. This second activity helps the students to develop their idea to make the connection from the context given with their own experience.

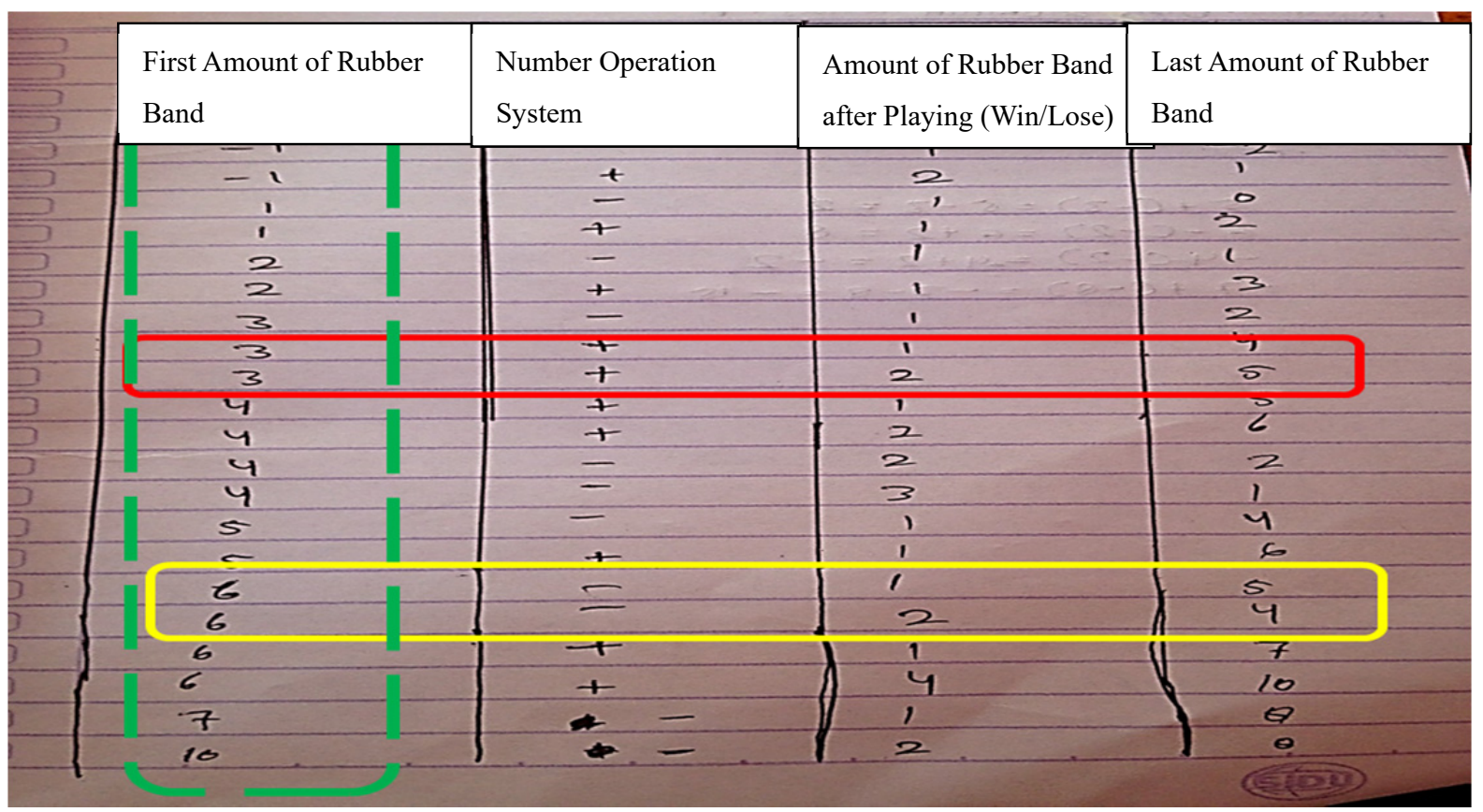

Figure 4. All Students' Observation Data

\subsubsection{Activity 3}

This activity is a crucial activity where the students can construct their knowledge as one model about integer from the one phenomenon in the game then using that model to apply in other events. In this activity, the teacher gives a challenge for the students to create and arranger their mathematics expression by continuing the order, either addition or subtraction operation. The teacher intends to let the students explore the mathematics expression given then arrange them by considering the ordering to realize the pattern of the mathematics expression. 


\section{Macrothink}
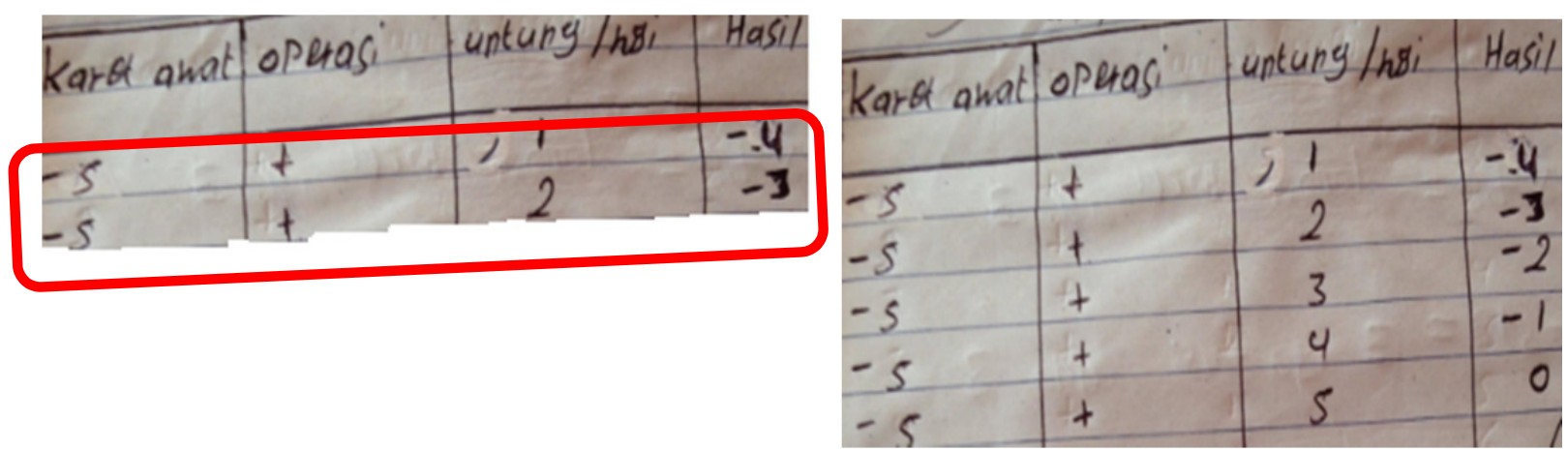

Figure 5. Students' Extension Mathematics Expression of Addition by 1

The left Figure 5 shows the two mathematics expressions from the data they collect during the game. First, the students try to arrange the number in order, then add by 1, extended the expression, and make five mathematics expressions in ordering increase by 1 become the picture showing on the right side.

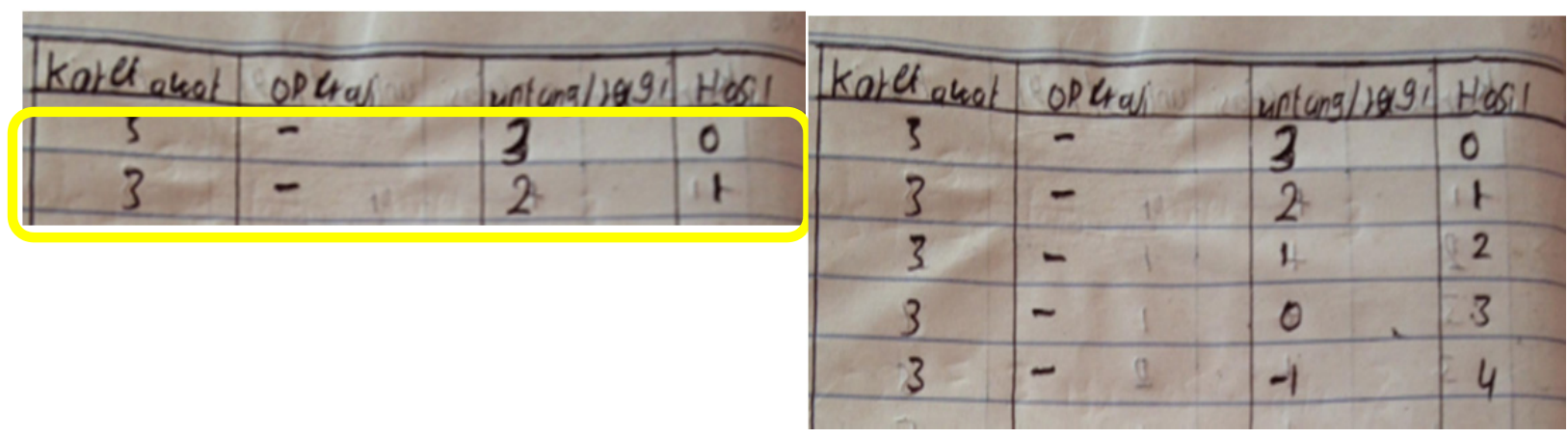

Figure 6. Students' Extension Mathematics Expression of Subtraction by 1

For these figures, the left ones show the two mathematics expressions from the data they collect as well then, by ordering and subtract by 1 , and she extended the expression. She made five mathematics expressions in ordering decrease by 1 become the figure showing on the right side of Figure 6 . Based on the samples above, the students are expected to move out from the context-bound (rubber game) without considering the winner or loser — still, the skills to see the pattern by extending the mathematics expression.

From this activity during the extension of the mathematics expression, students will construct their skills to distinguish the different meanings of the "minus" sign. Three meanings of "minus" sign are: "minus" as a subtraction symbol (it is showing how they can operate the subtraction by seeing whether they are won or lost, and as showing in the picture above relate to decreasing the mathematics expression). The second ones are "minus" as representation of negative number (e.g., negative 3 or -3 . It is showing from the first how they come to use minus sign for showing the borrowing context), and the last one is "minus" as the opposite of where more relate to the movement (ex. - (-4) means the opposite of negative 4 = positive 4).

When the students have an awareness of thinking mathematically, it will help them to learn 


\section{Ml Macrothink}

International Journal of Learning and Development

ISSN 2164-4063

2019, Vol. 9, No. 4

about formal mathematics and able to help them in increasing their ability to mathematize in any context in the future (Lipka, 1994; Adam, 2004). In this level, the ethnomathematical curriculum focuses on mathematics as a process, rather than a collection of facts. The model is base on the idea that mathematics is a human creation that emerges as people attempt to understand their world. In other words, ethnomathematics can be considered as a tool for the mathematization process. It will help students to develop various representations from different contexts.

\subsubsection{Activity 4}

In the last activity, the students are required to solve the problem. Students are required to present their result individually, and by choosing purposely, the teacher will guide the students to find out the common expression which has the same result.

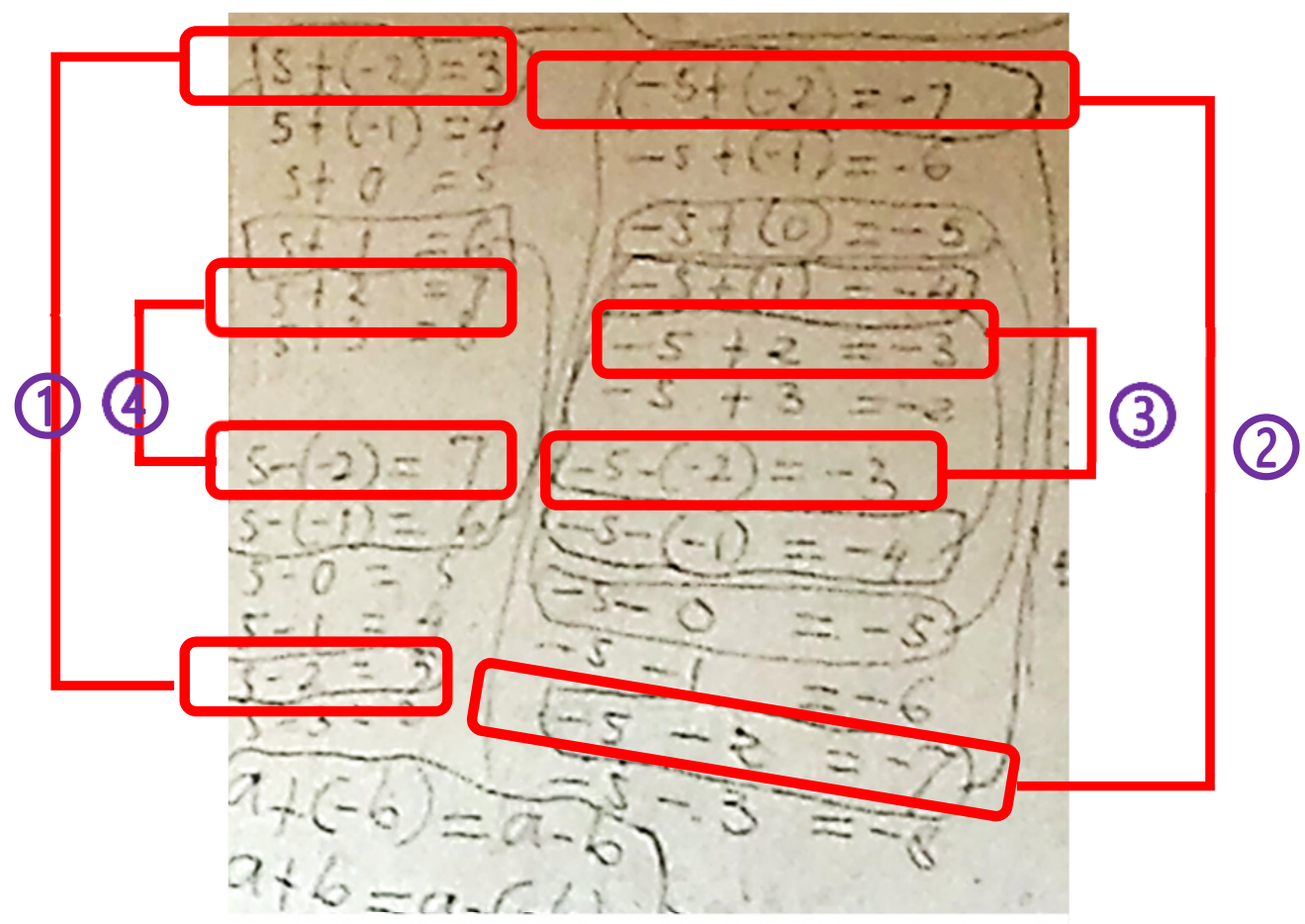

Figure 7. Students' Formal Mathematics

$$
\begin{array}{ll}
\text { (1) } 5+(2)=5-(-2)=7 & \rightarrow a+(b)=a-(-b) \\
\text { (2) }-5+(2)=-5-(-2)=-3 & \rightarrow-a+(b)=-a-(-b) \\
\text { (3) } 5+(-2)=5-2=3 & \rightarrow a+(-b)=a-b \\
\text { (4) }-5+(-2)=-5-2=-7 & \rightarrow-a+(-b)=-a-b
\end{array}
$$

The four-level of Realistic Mathematics Education is related to formal mathematics, which is to see how the students will going from the context bounded to be free bounded. In this stage, some of the expression is difficult to be express from the rubber game situation anymore. But by using the model-for table that they made, students able to find the formula as a conclusion of the objective of this lesson. Based on Utami et al. (2018), when the students can sort 
positive integers and negative integers, it means they understand the positive and negative symmetry properties (call as a formal mental model).

\section{Conclusion}

As shown as Bishop J.P, Lamb, Whitacre, Schappelle, and Lewis (2014), works how they identified the way of reasoning of integer, which consists of order, magnitude, logical necessity/formal (structural similarity), computational, and limited. The experiences from this implementation on ethnomathematics curriculum will be used neither as motivation, nor as an introduction, but as part of understanding how mathematical ideas develop, how they build into systems, how they are formulated, and how they are then applied in various ways within the culture. In this stage, teachers' role in appreciating each students' model, as well as students, will learn how to appreciate the diversity of the culture and opinion among them are crucial.

By valuing the diversity of culture as well as various mathematics way of thinking, ethnomathematics curriculum which consist in this level can be considered as a process of value. The limitation of this paper is the students' way to construct the meaning of the opposite of negative $2[-(-2)]$ only using the model of table, which cannot explain back by using the rubber game. But this type of table-model by students, hopefully, can be extended towards multiplication as well as division concept in integer.

\section{References}

Adam, S. (2004). Ethnomathematical Ideas in the Curriculum. Mathematics Education Research Journal, 16(2), 49-68. https://doi.org/10.1007/BF03217395

Alangui, W. (2017). 'Ethnomathematics and Culturally Relevant Mathematics Education in the Philippines.' In M. Rosa, L. Shirley, ME Gavarette \& W. Alangui (Eds.). Ethnomathematics and its Diverse Approaches for Mathematics Education. Cham: Springer International Publishing AG. https://doi.org/10.1007/978-3-319-59220-6_8

Battista, M. T. (1983). A Complete Model for Operations on Integers. Arithmetic Teacher, 30(9), 26-31. Retrieved from: http://elementarymathendorsent.pbworks.com/w/file/fetch/81159116/charge\%20model\%20ar ticle.pdf

Begg, A. (2001). Ethnomathematics: Why, and what else? Zentralblatt Für Didaktik Der Mathematik, 33(3), 71-74. https://doi.org/10.1007/bf02655697

Bellamy, A. (2015). A critical analysis of teaching and learning negative numbers. Philosophy of Mathematics Education Journal, 29. Retrieved from: http://socialsciences.exeter.ac.uk/education/research/centres/stem/publications/pmej/pome29/ index.html

Bishop, A. J. (1988). Mathematical enculturation. A cultural perspective on mathematics education. Dordrecht: Kluwer Academic Publishers. http://dx.doi.org/10.1007/978-94-009-2657-8 
Bishop, J. P., Lamb, L. L., Philipp, R. A., Whitacre, I., Schappelle, B. P. \& Lewis, M. L. (2014). Obstacles and affordances for integer reasoning: An analysis of children's thinking and the history of mathematics. Journal for Research in Mathematics Education, 45(1), 19-61. http://dx.doi.org/10.5951/jresematheduc.45.1.0019

Common Core Standard Initiative (CCSI). (2012). About the Standards. Retrieve from www.corestandards.org

De Los Santos, Estella. (2013). Understanding Integer Addition and Subtraction Concepts Using Microsoft Word ${ }^{\circledR}$ Illustrations. Ohio Journal of School Mathematics, 68, 8-14. Retrieved from https://kb.osu.edu/bitstream/handle/1811/78152/OJSM_68_Fall2013_08.pdf

Gravemeijer, K.P.E. (1994). Developing Realistic Mathematics Education. Utrecht: CD-Beta Press/Freudenthal Institute.

Gravemeijer, K. P. E., \& Cobb, P. (2006). Design research from a learning design perspective. In J. Akker, K. Gravemeijer, S. McKenney, \& N. Nieveen (Eds.), Educational design research (pp. 45-85). London: Routledge

Linchevski, L. \& Williams, J. (1999). Using Intuition from Everyday Life in 'Filling' the Gap in Children's Extension of Their Number Concept to Include the Negative Numbers. Educational Studies in Mathematics, 39(1-3), 131-147. https://doi.org/10.1023/A:1003726317920

Lipka, J. (1994). Culturally Negotiated Schooling: Toward a Yup'ik Mathematics. Journal of American Indian Education, 33, 14-30. Retrieved From: https://www.researchgate.net/publication/238212417_Culturally_negotiated_schooling_Towa rd_a_Yup'ik_mathematics

Lytle, P. A. (1994). Investigation of a model based on the neutralization of opposites to teach integer addition and subtraction. In J. P. da Ponte \& J. F. Matos (Eds.), Proceedings of the 18th International Conference for the Psychology of Mathematics Education (Vol. III, pp. 192-199). Lisbon, Portugal:University of Lisbon

Ministry of Education and Culture (MOEC). (2018). Development of curriculum. Jakarta: Kementerian Pendidikan dan Kebudayaan. Retrieved from https://www.kemdikbud.go.id/

National Council of Teachers of Mathematics (NCTM). (1997). Realistic Mathematical.

Peni, Nur Robiah Nofikusumawati. (2019). Development Framework of Ethnomathematics Curriculum through Realistic Mathematics Education Approach. IOSR Journal of Research \& Method in Education, $\quad 9(4), \quad$ 16-24. https://doi.org/10.9790/1959-0904011624www.iosrjournals.org Retrieved From http://www.iosrjournals.org/iosr-jrme/papers/Vol-9\%20Issue-4/Series-1/B0904011624.pdf

Peni, N. R. N., \& Baba, T. (2019). Consideration of Curriculum Approaches of Employing Ethnomathematics in Mathematics Classroom. Journal of Physics: Conference Series. 1321 032125. http://dx.doi.org/10.1088/1742-6596/1321/3/032125 


\section{Macrothink}

International Journal of Learning and Development

ISSN 2164-4063 2019, Vol. 9, No. 4

Schwarz, B. B., Kohn, A. S., \& Resnick, L. B. (1993-1994). Positives about negatives: A case study of an intermediate model for signed numbers. Journal of the Learning Sciences, 3(1), 37-92. https://doi.org/10.1207/s15327809j1s0301_2

Seeley, Cathy L. (2016). Making Sense of Math: How to Help Every Student Become A Mathematical Thinker and Problem Solver. Association for Supervision \& Curriculum Development.

Sembiring, R. K., Hadi, S., Dolk, M. (2008). Reforming Mathematics Learning in Indonesian Classroom through RME. ZDM Mathematics Education, 40, 927-939. http://dx.doi.org/10.1007/s11858-008-0125-9

Smith, J. P. (1995). The Effects of a Computer Microworld on Middle School Students' Use and Understanding of Integers. (Unpublished doctoral dissertation). The Ohio State University, Columbus, Ohio. Retrieved from: http://rave.ohiolink.edu/etdc/view?acc_num=osu1248798217

Stephan, Michelle., Akyuz, Didem. (2012). A Proposed Instructional Theory for Integer Addition and Subtraction. Journal for Research in Mathematics Education, 43(4), 428-464. http://dx.doi.org/10.5951/jresematheduc.43.4.0428

Streefland, L. (1996). Negative numbers reflections of a learning researcher. Journal of Mathematical Behavior, 15(1), 57-79. https://doi.org/10.1016/S0732-3123(96)90040-1

TESS-India. (2012). Mathematical Stories: Word Problems. The Open University UK and UK aid. Retrieved June 10, 2016, from http://www.open.edu/openlearnworks/pluginfile.php/134932/mod_resource/content/3/EM04 AIE_Final.pdf

Thompson, P. W., \& Dreyfus, T. (1988). Integers as transformations. Journal for Research in Mathematics Education, 19(2), 115-133. https://doi.org/10.2307/749406

Utami, A. D., Sa'dijah, C., Subanji, \& Irawati, S. (2018). Six Levels of Indonesian Primary School Students' Mental Model in Comprehending the Concept of Integer. International Journal of Instruction, 11(4), 29-44. https://doi.org/10.12973/iji.2018.1143a

Zaslavsky, C. (1991). Multicultural Mathematics Education for the Middle Grades. Arithmetic Teacher, 38(6), 8-13. Retrieved from https://www.jstor.org/stable/41194762

\section{Copyright Disclaimer}

Copyright for this article is retained by the author(s), with first publication rights granted to the journal.

This is an open-access article distributed under the terms and conditions of the Creative Commons Attribution license (http://creativecommons.org/licenses/by/4.0/). 